\title{
Perlindungan Ekspresi Budaya Tradisional di Indonesia: Suatu Penilaian Undang-undang
}

\author{
(Protection of Traditional Cultural Expression in Indonesia: \\ A Legal Assessment)
}

\author{
AYU CITRA SANTYANINGTYAS \\ RASYIKAH MD KHALID \\ NUR FADZLUN JOHAN
}

\begin{abstract}
ABSTRAK
Ekspresi budaya tradisional Indonesia merupakan warisan Indonesia yang tidak ternilai dan menjadi identiti kebangsaan. Namun begitu, terdapat pihak yang cuba untuk mempergunakan ekspresi budaya tradisional Indonesia ini sebagai hasil pendapatan mereka dan mempatenkan ekspresi budaya tradisional ini sehingga menyebabkan masyarakat tradisional Indonesia sendiri tidak boleh menggunakan ekpresi budaya tradisional ini. Maka dengan itu dalam penyelidikan ini melihat usaha yang dilakukan oleh kerajaan Indonesia untuk mempertahankan ekspresi budaya tradisional. Antara usaha yang dilakukan adalah Rang Undang-undang Pengetahuan Tradisional dan Ekpresi Budaya Tradisional yang akan dibentang dan digubal untuk melindungi ekspresi budaya tradisional di Indonesia.
\end{abstract}

Kata Kunci: Warisan, Ekspresi budaya tradisional, Indonesia, Undang-undang

\section{ABSTRACT}

The traditional cultural expression of Indonesia is Indonesia's priceless heritage and is a symbol of national identity. However, there are those who try to use this traditional cultural expression for income generation. They have also patented the priceless heritage so much so that they deprive the right of traditional Indonesian communities to use the patented traditional cultural expression. This research aims at investigating efforts carried out by the Indonesian government to protect their traditional cultural expression. Among the efforts made is the drafting of the Traditional Knowledge and Traditional Cultural Expressions Bill which will formalize the protection of traditional cultural expression in Indonesia.

Keywords: Heritage, Traditional cultural expression, Indonesia, Law

\section{PENGENALAN}

Indonesia merupakan sebuah negara yang kaya dengan kepelbagaian ekspresi kebudayaan tradisional. Kepelbagaian ekspresi kebudayaan tradisional terhasil daripada kreativiti masyarakat tradisional dan berpotensi untuk menjadi sumber pembangunan ekonomi Indonesia. Indonesia berpotensi besar untuk menghasilkan pelbagai produk dan budaya tradisional kerana dari seluruh wilayah di Indonesia, dari Sabang sehinggalah ke
Merauke, terdapat lebih daripada 900 suku yang menetap di 33 wilayah di Indonesia (Restu Gunawan 2014).

Walaupun Indonesia mempunyai kepelbagaian ekspresi budaya tradisonal, namun begitu terdapat masalah yang wujud iaitu negara maju telah menggunakan hasil kreativiti masyarakat tradisional untuk dijadikan sebagai sumber pendapatan mereka dan ini telah menyebabkan berlakunya kerugian besar yang perlu ditanggung oleh kerajaan Indonesia akibat pemanfaatan tersebut. Dalam era 
perdagangan bebas, banyak negara maju yang mula mencari produk baharu sebagai alternatif untuk berdagang dalam meningkatkan ekonomi suatu bangsa. Satu aspek semasa dan baharu yang muncul untuk meningkatkan perekonomian negara ialah ekonomi yang berasaskan pada ekspresi budaya tradisional dan penggunaan sumber semula jadi. Sejak kebelakangan ini negara maju mula menggunakan sumber semula jadi dan harta intelek warisan budaya masyarakat tradisional di negara membangun atau bekas negara jajahan mereka untuk dijadikan sumber pendapatan mereka.

Kemunculan negara maju dalam menggunakan ekspresi budaya tradisional menimbulkan rasa tidak puas hati dan ketidakadilan kepada negara membangun, seperti Indonesia kerana ekspresi budaya tradisional mereka tidak mendapat perlindungan yang sewajarnya. Keengganan negara maju untuk mengiktiraf ekspresi budaya tradisional di negara membangun adalah kerana mereka tidak mahu kehilangan akses terhadap ekspresi budaya tradisional yang terbukti sangat menguntungkan mereka, sama ada secara ekonomi atau teknologi. Dalam konteks ini, Agus Sardjono menyatakan bahawa negaranegara maju tidak adil dalam penggunaan ekspresi budaya tradisional milik masyarakat tradisional di negara dunia ketiga. Beliau telah merujuk satu kes penggunaan warisan budaya tradisional milik kerajaan Indonesia yang telah digunakan oleh negara maju di Bali iaitu kes I Ketut Dany Ariyasa, seorang pereka tempatan di Bali, yang mendakwa bahawa PT Karya Tangan Indah (KTI) telah menggunakan rekaan motif kulit buaya dengan rekaan motif bunga yang dimiliki oleh masyarakat tradisional Bali Indonesia. Dalam kes ini, seorang pereka warganegara Amerika Syarikat telah menggunakan bentuk dan perhiasan etnik Bali sebagai objek reka bentuk dan telah mendapat hak cipta terhadapnya. Kemudian, hak cipta ini diperjualbelikan dalam kalangan pengusaha asing (Agus Sarjono 2011).

Dalam prosiding mahkamah, I

Ketut Dany Ariyasa dituduh oleh pengusaha asing tersebut dengan tuduhan pelanggaran hak cipta, iaitu menciplak reka bentuk kraftangan perak dengan konsep "bunga" miliknya. Namun, I Ketut Dany Ariyasa berpendapat bahawa motif bunga yang telah digunakan oleh pengusaha asing tersebut, merupakan milik nenek moyang masyarakat tradisional Bali, dan sesiapa pun berhak memakainya. Beliau penuh yakin bahawa motif bunga tersebut ialah nilai-nilai budaya tradisional warisan nenek moyang orang Bali yang boleh digunakan oleh sesiapa sahaja dan tidak boleh dijadikan sebagai milik peribadi seseorang atau kelompok tertentu. I Ketut Dany Ariyasa berjaya menyakinkan mahkamah bahawa reka bentuk motif bunga tersebut sepenuhnya milik masyarakat tradisional Bali dan tidak boleh dituntut sebagai milik individu atau kelompok (Detik News 2008).

Kes pelanggaran hak cipta pada rekaan motif bunga di ukiran perak tersebut menurut Agus Sardjono (2009) merupakan suatu falsafah hidup milik masyarakat tradisional Bali, di mana negara-negara maju telah menggunakan regim hak cipta mempunyai pemikiran bahawa ekspresi budaya tradisional tersebut sebagai domain awam (Michael Blankey 2001; Terri Janke 1998). Masyarakat tradisional di Bali, menggunakan nilainilai kebersamaan dan tidak berorientasikan nilai ekonomi sematamata, melainkan keagamaan (Darrel 
Addison Posey 2011), dengan gagasan hidup bersama (Tom G. Palmer 2007).

Selain itu, menurut Afriyana Purba pada tahun 2010 sehingga kini, terdapat 31 kes dalam penggunaan warisan kebudayaan tradisional yang dimiliki oleh masyarakat tradisional dan menyebabkan kerugian yang dialami oleh rakyat Indonesia sebanyak USD11.8 juta (Afriliyana Purba 2012). Antara aset dan objek ekspresi budaya tradisional Indonesia yang dituntut

JADUAL 1. Aset Ekspresi Budaya Tradisional yang telah dituntut oleh Negara Asing

\begin{tabular}{lll}
\hline Bil. & Jenis Aset Budaya Daerah & $\begin{array}{l}\text { Negara yang Memanfaatkan Warisan Budaya } \\
\text { Orang Asli }\end{array}$ \\
\hline 1. & Motif Batik Cirebon & Inggeris \\
2. & Motif Batik Pesisir & China \\
3. & Rendang & Belanda \\
4. & Sambal Bajak & Belanda \\
5. & Sambal Petai & Belanda \\
6. & Sambal Nanas & Belanda \\
7. & Motif Ukiran Jepara & Perancis \\
8. & Tempe & Thailand \\
9. & Perhiasa Khas Jepara & Inggeris \\
10. & Motif Bunga Perak Bali & Amerika Syarikat \\
\hline
\end{tabular}

Sumber: Dewan Pelestarian Nilai Budaya (2015)

Jadual di atas membuktikan bahawa terdapat banyak kes penggunaan warisan kebudayaan tradisional yang dihasilkan oleh masyarakat tradisional dan menghasilkan nilai ekonomi kepada pihak-pihak mahupun institusi-institusi yang berasal dari negara maju. Dengan ketiadaan undang-undang yang menyeluruh untuk melindungi ekspresi budaya tradisional, masyarakat tradisional secara khususnya dan negara Indonesia secara amnya akan mengalami kerugian daripada aspek ekonomi mahupun perkembangan budaya bangsa.

Berdasarkan kes ini, perlindungan pada ekspresi budaya tradisional perlu dilakukan oleh kerajaan Indonesia. Hal ini penting untuk mencegah penyalahgunaan produk ekspresi budaya tradisional milik masyarakat tradisional oleh negara lain tanpa izin. Peruntukan oleh negara maju termasuk batik, skrip kuno, bahan masakan, lagu, tarian, alat muzik, rekaan, produk tanaman dan sebagainya.

undang-undang tentang perlindungan ekspresi budaya tradisional menjadi penting sebagai pertimbangan keadilan kepada masyarakat tradisional serta memelihara dan memulihara ekspresi budaya tradisional di Indonesia. Perlindungan ekspresi budaya tradisional berperanan positif dalam memberikan sokongan kepada masyarakat tradisional dalam memelihara tradisi mereka.

Penggunaan ekspresi budaya tradisional menjadi masalah kerana ekspresi budaya tradisional digunakan tanpa izin atau kebenaran daripada kerajaan Indonesia ataupun masyarakat tradisional. Oleh sebab itu, kerajaan Indonesia perlu mengambil langkah serius untuk melindungi ekspresi budaya tradisional sebagai harta intelek yang juga dapat memberikan perlindungan kepada hak-hak komuniti masyarakat tradisional setempat. Dalam perkembangan yang sama, 
terdapat banyak kes penggunaan warisan budaya tradisional yang dihasilkan oleh masyarakat tradisional, seperti perniagaan kraftangan yang telah diciplak dan digunakan sebagai hasil negara maju. Hal ini kerana belum ada undang-undang yang jelas yang dibuat oleh kerajaan Indonesia tentang penggunaan warisan budaya tradisional oleh pihak asing atau negara lain, dan ini merugikan pemilik warisan budaya tradisional, iaitu masyarakat tradisional (Eva Damayanti 2002).

Secara amnya, perlindungan ekspresi budaya tradisional dibuat melalui undang-undang yang berkaitan dengan harta intelek. Perundangan yang sedia ada dalam memberikan perlindungan kepada harta intelek ialah Undang-Undang No. 28 Tahun 2010 tentang Hak Cipta, di mana fasal 10 memperuntukkan bahawa:

1. Negara memegang hak cipta terhadap karya peninggalan prasejarah, sejarah dan budaya kebangsaan yang lain.

2. Negara memegang hak cipta terhadap budaya rakyat dan hasil kebudayaan rakyat yang menjadi milik bersama, seperti cerita, hikayat, dongeng, legenda, babad, lagu, kraftangan, koreografi, tarian, kaligrafi, dan karya seni yang lain.

Namun begitu fasal 10 tidak menjelaskan tentang maksud dan cara perlindungan yang diberikan kepada ekspresi budaya tradisional milik masyarakat tradisional. Sungguhpun demikian, sehingga kini belum ada undang-undang yang komprehensif dan efektif di Indonesia yang mengatur tentang perlindungan ekspresi budaya tradisional. Justeru, kajian ini untuk melihat perlindungan ekspresi budaya di Indonesia.

\section{KONSEP PERLINDUNGAN EKSPRESI BUDAYA}

Ekspresi budaya tradisional merupakan warisan budaya dunia yang memiliki ciri-ciri khas dan hanya dimiliki oleh satu negara untuk menjaga warisan tersebut. Ekspresi budaya tradisional dilindungi sebagai warisan dunia kerana bentuk ekspresi budaya tradisional tersebut telah diwariskan dari generasi ke satu generasi yang lain secara turun-temurun, yang tetap dipelihara, dilindungi, dihargai dan dijaga pemilikannya (I Wayan Ardika 2007)

Secara estimologi, ekspresi budaya tradisional merangkumi ekspresi pengungkapan atau proses seperti maksud, gagasan, perasaan, manakala kata budaya dalam bahasa Inggeris disebut sebagai "culture" yang berhubungan dengan makna kebudayaan yang berasal daripada bahasa Sanskrit, iaitu "budhayah" yang bererti budi atau akal (Clifford Geertz 1973). Secara umumnya, kebudayaan dapat didefinisikan sebagai sesuatu yang dihasilkan oleh akal fikiran manusia agar dapat melangsungkan dan mempertahankan hidup dalam persekitarannya.

Menurut Edy Sedyawati (2003), menyatakan bahawa secara umumnya ekspresi budaya tradisional merangkumi segala bentuk ungkapan budaya yang bersifat ekspresif khususnya ungkapan seni di mana penciptanya tidak diketahui dan diturunkan secara lisan. Selain itu, warisan ekspresi budaya tradisional juga merupakan kepercayaan rohani, identiti budaya, pandangan dunia, dan undang-undang adat (Sarah Harding 2003). Orang asli menganggap bahawa ekpresi budaya tradisional merupakan milik komuniti di mana mereka berasal, dan adalah penting untuk 
menentukan sendiri (Peter Drahos 2007). Orang-orang asli mempunyai keprihatinan terhadap penjagaan rohani objek dan ungkapan dan konteks di mana karya mereka digunakan. Ungkapan tersebut sering dianggap suci dan tidak boleh dikongsi dengan masyarakat di luar komuniti mereka.

Ekspresi budaya tradisional merupakan kekayaan Indonesia yang tidak ternilai dan menjadi identiti kebangsaan. Oleh yang demikian, ekspresi budaya tradisional juga ditakrifkan sebagai pengetahuan yang sangat penting untuk dimiliki (atau dikuasai) dan digunakan oleh komuniti atau kumpulan masyarakat tradisional tertentu dan berubah sesuai dengan perubahan zaman dan persekitaran (Lembaga Pengkajian Hukum Internasional Fakultas Hukum Universitas Indonesia bekerjasama dengan Ditjen HKI Departemen Hukum dan HAM 2005). Antara hasil karya ekspresi budaya tradisional yang telah diketahui umum di Indonesia adalah ukiran jati masyarakat Jepara yang telah mempunyai reka bentuk yang khas dari Indonesia; batik Cina yang merupakan produk tekstil daripada masyarakat tradisional di pesisir pantai utara Jawa; rendang, sambal petai dan sambal bajak yang merupakan produk makanan khas masyarakat tradisional Padang; serta reog ponorogo yang merupakan seni tradisional masyarakat Ponorogo (Tri Harjun Ismaji 2009).

Pada fasal 8 (J) Konvensyen Kepelbagaian Biologi (CBD) 1992 , pengetahuan tradisional merujuk kepada pengetahuan, inovasi dan amalan masyarakat tradisional dan tempatan di seluruh dunia (Krystyna Swiderskal, Elenita Dano \& Olivier Dubois 2001). Ekspresi budaya tradisional dibangunkan daripada pengalaman yang diperoleh sekian lama abadnya dan disesuaikan dengan budaya dan persekitaran tempatan serta pengetahuan tradisional disampaikan secara lisan dari satu generasi ke generasi yang lain (Yulia \& Zainul Ashikin Zainol 2013). Ekspresi budaya tradisional cenderung untuk dimiliki secara kolektif. Adapun yang termasuk di dalam ekspresi budaya tradisional ialah cerita, lagu, cerita rakyat, peribahasa, nilai budaya, mitos dan kepercayaan agama (Abdul Atsar 2017).

Perlindungan ekspresi kebudayaan tradisional merupakan produk yang mempunyai ciri-ciri unik daripada masyarakat tradisional dan telah menjadi milik masyarakat tradisional yang digunakan sebagai sebahagian daripada identiti budaya atau sosial atau warisan mereka. Beberapa pengertian di atas menggambarkan bahawa ekspresi budaya tradisional ialah: ${ }^{1}$

1. Produk aktiviti intelektual kreatif dan termasuk kreativiti masyarakat;

2. Mempunyai nilai-nilai asli dan identiti budaya dan sosial dan warisan budaya masyarakat dan masyarakat budaya tradisional dan lain-lain; dan

3. Dikekalkan, digunakan atau dibangunkan oleh bangsa, negara yang merupakan hasil dari kreativiti masyarakat tradisional.

Menurut World Intellectual Property Organization (WIPO), ekspresi budaya tradisional ialah ungkapan cerita rakyat termasuk muzik, seni, reka bentuk, nama, tanda, simbol, persembahan, bentuk seni bina, kraftangan dan naratif. Berdasarkan makna yang diberikan oleh WIPO (M Zulfa Aulia 2006), kriteria yang termasuk dalam warisan budaya tidak ketara ialah: 
1. Diajarkan dan dilaksanakan oleh generasi ke generasi;

2. Berkembang secara dinamik;

3. Bersatu atas nama identiti suatu komuniti; dan

4. Merupakan sumber kreativiti dalam masyarakat.

Ekspresi budaya tradisional merupakan sebahagian daripada kehidupan suatu masyarakat pemilik budaya tersebut yang mengandungi nilai ekonomi, adat termasuk upacara agama mahupun hasil kreativiti dari komuniti masyarakat tradisional. Warisan budaya tradisional menjadi identiti sesebuah masyarakat tradisional di sesebuah daerah. Oleh itu, menurut Eva Damayanti (2012) warisan budaya tradisional tersebut merangkumi:

1. Ungkapan teks, sama ada lisan dan dalam bentuk tertulis, yang membentuk prosa dan puisi dalam pelbagai tema dan pesanan kandungan,serta boleh menjadi naratif sastera atau maklumat;

2. Muzik, termasuk vokal dan alat muzik instrumental;

3. Gerakan, termasuk, tarian, seni mempertahankan diri dan permainan;

4. Wayang, termasuk pertunjukan boneka dan drama rakyat;

5. Seni, sama ada dalam bentuk dua dimensi dan tiga dimensi yang dibuat dari pelbagai bahan seperti kulit, kayu, rotan, logam, seramik dan tekstil;

6. Upacara adat termasuk perbuatan alat dan bahan dan persembahan mereka.

Oleh itu, boleh disimpulkan bahawa ekspresi budaya tradisional merupakan ungkapan budaya yang berkaitan dengan masyarakat tradisional sama ada dari segi cara hidup, pemakaian, makanan, seni bina, muzik, cerita rakyat dan sebagainya. Ekspresi budaya ini merupakan warisan daripada nenek moyang terdahulu dan perlu dijaga supaya ianya tidak ditelan zaman kerana warisan ini kadang kala ditinggalkan dalam bentuk lisan secara turun temurun. Maka dengan itu, ekspresi budaya tradisional ini perlu dilindungi oleh undang-undang supaya tiada pihak menggunakannya untuk kepentingan peribadi.

\section{PERLINDUNGAN EKSPRESI \\ BUDAYA TRADISIONAL DALAM UNDANG-UNDANG DI INDONESIA}

Ekspresi budaya tradisional merupakan sebuah bentuk identiti budaya masyarakat dan di dalamnya terdapat hak masyarakat tradisional tersebut. Maka, perlindungan terhadap ekspresi budaya tradisional perlu dilakukan untuk menghormati dan melindungi hak-hak masyarakat tradisional. Hal ini kerana ianya terhasil daripada manifestasi ekspresi budaya yang telah dibangunkan secara turun-temurun, sama ada budaya ketara atau tidak ketara yang merangkumi tarian, muzik, simbol, motif pakaian dan lain-lain. Menurut hak asasi manusia, negara wajib untuk memelihara dan melindungi amalan-amalan tradisional, pengetahuan tradisional dan cara hidup yang terdapat dalam masyarakat tradisional sebagai ekspresi budaya tradisional suatu bangsa. Namun begitu, masyarakat tradisional Indonesia masih lagi tidak dapat menikmati hasil daripada karya ekspresi budaya tradisional.

Oleh itu, dalam bahagian ini melihat sama ada undang-undang yang sedia ada di Indonesia ini mampu untuk memberi perlindungan terhadap ekspresi budaya tradisional. Antara 
undang-undang yang dlihat adalah Undang Undang-undang Dasar Republik Indonesia Tahun 1945 dan Undang-undang Hak Cipta No 28 Tahun 2014.

\section{UNDANG-UNDANG DASAR REPUBLIK INDONESIA TAHUN 1945}

Penggubalan undang-undang ini dibuat atas dasar norma-norma kebangsaan dan bernegara maka, terbentuklah Undang-undang Dasar Republik Indonesia Tahun 1945. Penggubalan ini dibuat oleh Panitian Persiapan Kemerdekaan Indonesia yang bertindak sebagai Badan Penggegas yang membentuk Republik Indonesia (Sutejo K. Widodo 2004). Undangundang Dasar Republik Indonesia Tahun 1945 merupakan undangundang bertulis dan merupakan undang-undang yang tertinggi di Indonesia. Undang-undnag ini merupakan garis panduan untuk penggubalan peraturan perundangan yang lain. Selain itu, undang-undang, peraturan atau dasar yang dirangka atau digubal mestilah tidak bercanggah dengan Undang-undang Dasar Republik Indonesia Tahun 1945 (Miriam Budiarjo 2003).

Fasal 28 (3) Undang-Undang Dasar Republik Indonesia Tahun 1945 ada menyebutkan mengenai suatu identiti ekspresi budaya tradisional dan hak masyarakat tradisional hendaklah dihormati selaras dengan perkembangan zaman dan peradaban. Fasal 32 Undang-Undang Dasar Republik Indonesia Tahun 1945 menegaskan bahawa pemerintah perlu melindungi ekspresi budaya tradisional negara Indonesia serta di dalam Penjelasan Undang-Undang Dasar Republik Indonesia Tahun 1945 telah dinyatakan bahawa usaha untuk melindungi ekspresi budaya tradisional harus menuju ke arah kemajuan negara dan kelulusan dengan tidak menolak bahan-bahan baru dari kebudayaan asing yang dapat memberi perkembangkan atau memperkaya kebudayaan bangsa sendiri, atau meninggikan darjat kemanusiaan bangsa Indonesia.

Namun begitu, perlindungan ekspresi budaya tradisional dalam Undang-undang Dasar Republik Indonesia ini boleh dilihat sebagai bersifat umum dan ianya tidak cukup untuk memberi perlindungan yang sewajarnya kepada ekspresi budaya tradisional yang didokong oleh masyarakat tradisional Indonesia. Oleh itu, Indonesia sebagai pemilik daripada ekspresi budaya tradisional wajib melindungi ekspresi tersebut di pertengahan peradaban dunia dan memelihara nilai-nilai warisan ekspresi budaya tradisional.

\section{UNDANG-UNDANG HAK CIPTA NO 28 TAHUN 2014}

Dalam kajian ini melihat bagaimana perlindungan ekspresi budaya tradisional dibuat melalui sistem undang-undang hak cipta. Perlindungan melalui undang-undang hak cipta ini telah dilakukan semenjak tahun 1982 sehingga kini, namun ianya masih lagi terdapat berlakunya pelanggaran yang dibuat oleh pihak asing terutama negara maju terhadap ekspresi budaya tradisional ini.

Harta intelek merupakan suatu hak yang timbul daripada tindakan yang berasal daripada kreativiti manusia (Jamaludi Abu Bakar 2002). Hasil kreativiti manusia tersebut dalam bentuk karya teknologi, ilmu pengetahuan, seni dan sastera. Secara umum harta intelek terdiri daripada dua jenis hak iaitu hak kekayaan industri dan hak cipta (Jamaludi Abu Bakar 2002). Hak kekayaan industri terdiri daripada paten, cap dagangan, reka bentuk perindustrian, reka bentuk susun atur litar bersepadu, jenis 
tumbuhan, petunjuk geografi. Hak cipta terdiri daripada hasil karya asli dalam bentuk ilmu pengetahuan, seni dan sastera (OK Saidin 2010).

Menurut David Bainbridge (2010), apa-apa yang telah dihasilkan oleh akal fikiran manusia adalah wajib diberikan perlindungan undangundang. Copinger \& et al (1998) dalam bukunya merumuskan bahawa seorang pengarang suatu karya adalah menjadi pemilik pertama hak cipta di dalam karyanya. Hal tersebut senada dengan pengertian dalam Fasal 1 (2) UndangUndang Hak Cipta No. 28 tahun 2014 mendefinisikan bahawa pencipta ialah seorang atau beberapa orang secara bersama-sama melahirkan satu inspirasi iaitu ciptaan yang berdasarkan fikiran, bayangan, keterampilan atau keahlian yang dihasilkan dalam bentuk yang khas dan bersifat peribadi (Fasal 1 (2), UU No. 19 Tahun 2014, Undang-Undang Tentang Hak Cipta).

Selain itu, dalam fasal 1 (1), Undang-Undang Hak Cipta No. 28 tahun 2014 menyatakan bahawa hak cipta ialah hak eksklusif bagi pencipta atau penerima hak untuk mengumumkan atau memperbanyak ciptaannya atau memberikan kebenaran untuk itu dengan tidak mengurangi pembatasan-pembatasan yang telah termaktub dalam peraturan perundangan sedia ada. Di samping itu juga, dalam fasal 5 Undang-Undang Hak Cipta No. 28 tahun 2014 menyatakan bahawa hak cipta meliputi hak tunggal pencipta untuk membuat, menerbitkan dan memberi kuasa untuk membuat terjemahan dari karya yang dilindungi.

Perlindungan ekspresi budaya tradisional melalui UUHC No.28 tahun 2014 pada fasal 10 memberikan pengertian tentang ekspresi budaya tradisional iaitu:

1. Negara merupakan pemegang hak cipta ke atas karya peninggalan prasejarah, sejarah, dan budaya nasional lainnya.

2. Negara merupakan pemegang hak cipta ke atas cerita rakyat dan hasil kebudayaan rakyat yang menjadi milik bersama, seperti cerita, hikayat, dongeng, legenda, kisah riwayat, lagu, kepakaran tangan, koreografi, tarian, kaligrafi, dan karya seni lainnya.

3. Untuk mengumumkan atau memperbanyak ciptaan tersebut pada ayat (2), orang yang bukan warganegara Indonesia harus terlebih dahulu mendapat kebenaran dari badan yang berkaitan dalam masalah tersebut.

4. Ketentuan lebih lanjut mengenai hak cipta yang dipegang oleh negara sebagaimana dimaksud dalam Fasal ini, diatur dengan Peraturan Pemerintah.

Namun begitu, hak cipta memiliki beberapa kelemahan yang menghalang pengaturan perlindungan atas karya-karya ekspresi budaya tradisional. Perlindungan hak cipta terhadap suatu karya cipta minimum 50 tahun setelah pencipta meninggal dunia. Pemberian tempoh perlindungan pada hasil ciptaan ialah untuk memberikan waktu kepada pencipta untuk menggunakan hak-hak ekonomi dalam ciptaannya untuk memperoleh imbalan ekonomi. Oleh itu, perlindungan hak cipta perlu berterusan, walaupun penciptanya sudah meninggal dunia kerana karya ekspresi tradisional ini berkembang mengikut zaman dan digunakan secara turun-temurun. Selain itu, kelemahan Undang-undang Hak Cipta No 28 boleh dilihat pada fasal 1 (3) UndangUndang Hak Cipta No. 28 tahun 2014 di mana karya-karya yang dilindungi 
harus bersifat asli dan suatu karya tersebut tidak boleh meniru karya pencipta lainnya, sedangkan ekspresi budaya tradisional merupakan ekspresi budaya tradisional yang dibuat secara turun-temurun. Maka dengan itu, Indonesia memerlukan undang-undang yang betul-betul dapat mempertahankan dan memerlihara ekpresi budaya tradisional ini supaya tidak wujud penyalahgunaan oleh pihak asing terutama negara maju untuk kepentingan komersial mereka.

\section{PEMBENTUKAN RANG UNDANG- UNDANG PENGETAHUAN TRADISIONAL DAN EKSPRESI BUDAYA TRADISIONAL (RUU-PTEBT) DI INDONESIA}

Perlindungan terhadap ekspresi budaya tradisional di Indonesia diperlukan supaya tidak berlaku penyalahgunaan budaya tradisional tradisional ini. Hal ini kerana penggunaan ekspresi budaya tradisional oleh negara maju telah menimbulkan rasa kecewa bagi rakyat Indonesia khususnya masyarakat tradisional. Di Indonesia perlindungan ekspresi budaya tradisional ini hanyalah berdasarkan peruntukan hak cipta iaitu peruntukan fasal 10 Undangundang Hak Cipta 28 2014, namun begitu peruntukan dalam hak cipta ini terutama bagi perlindungan ekpresi budaya tradisional ini masih lagi lemah. Oleh itu, Indonesia merangka satu rang undang-undang yang baharu untuk memberikan perlindungan terhadap budaya tradisional iaitu dengan pembentukan Rang Undangundang Pengetahuan Tradisional dan Ekspresi Budaya Tradisional (RUUPTEBT). Rang undang-undang ini merupakan usaha kerajaan Indonesia untuk memberikan perlindungan terdapat ekspresi budaya tradisional dan memberi pengiktirafan undangundang adat sebagai bentuk perlindungan ekspresi budaya tradisonal.

RUU-PTEBT dirangka untuk membentuk rumusan undang-undang dalam memberi perlindungan ekspresi kebudayaan tradisional serta memberi arah bagi setiap pihak yang melaksanakan kegiatan pengurusan kebudayaan di Indonesia. Antara peruntukan dalam RUU-PTEBT adalah fasal 4 (1) menyatakan bahawa kerajaan dan pihak berkuasa daerah wajib melindungi pengetahuan tradisional dan ekspresi budaya tradisional. Manakala dalam fasal 4 (2) disebutkan bahawa bentuk perlindungan pengetahuan tradisional dan ekspresi budaya tradisional termasuk pencegahan dan/atau larangan terhadap:

1. Penggunaan oleh mana-mana orang asing yang dalam pelaksanaan penggunaannya tidak menyebut dengan jelas asal usul rantau ini dan masyarakat atau masyarakat yang menjadi sumber pengetahuan tradisional dan ekspresi budaya tradisional; dan / atau

2. Eksploitasi mana-mana orang asing yang tidak betul, salah arah dan tidak wajar dikenakan ke atas komuniti yang berkenaan, atau yang membuat masyarakat merasa tersinggung, dipermalukan dan tercemar.

Selain itu, dalam fasal 18 (1), (2), dan (3) RUU-PTEBT memperuntukkan mengenai pembahagian hasil pemanfaatan antara pihak yang melakukan pemanfaatan dengan pihak pemilik pengetahuan tradisional dan ekspresi budaya tradisional (Dirjen HKI - Dept. Hukum dan HAM RI 2009): 
1. Pihak yang melakukan pemanfaatan wajib memberi sebahagian dari hasil pemanfaatan kepada pemilik pengetahuan tradisional dan ekspresi budaya tradisional.

2. Dalam hal pemanfaatan sebagaimana dimaksud pada (1) menghasilkan karya baru, pemilik pengetahuan tradisional dan ekspresi budaya tradisional berhak memperoleh pembahagian keuntungan atas komersialisasi karya baru tersebut.

3. Pembahagian hasil pemanfaatan sebagaimana dimaksud pada (1) dan keuntungan atas komersialisasi karya baru sebagaimana dimaksud pada (2) ditentukan berdasarkan kesepakatan.

Fasal 2 (2) RUU-PTEBT menyebutkan bahawa ekspresi budaya tradisional yang dilindungi meliputi idea, konsep, kemahiran, pembelajaran dan amalan kebiasaan yang lain, dan inovasi yang membentuk gaya hidup masyarakat tradisional. Hal ini termasuklah pengetahuan rawatan seperti ubat berkaitan dan tata cara penyembuhan, pengetahuan tentang ruang dan waktu, pengetahuan pertanian, pengetahuan lingkungan alam, pengetahuan tentang flora dan fauna, pengetahuan tentang zat dan bahan mentah, pengetahuan tentang anatomi tubuh, pengetahuan tentang astronomi, ekspresi budaya tradisional, serta pengetahuan yang berkaitan dengan sumber genetik.

Cara perkongsian faedah yang ditawarkan dalam menjawab usaha pemanfaatan ekspresi budaya tradisional boleh dipertimbangkan sebagai pilihan yang dianggap tepat. Syarat dan tata cara permohon kebenaran akses pemanfaatan sebagaimana merujuk pada fasal 6 RUU-PTEBT bahawa:

1. Permohonan kebenaran akses pemanfaatan diajukan secara tertulis dalam bahasa Indonesia kepada Menteri Pendidikan dan Kebudayaan melalui Gabenor.

2. Gabenor bertanggungjawab terhadap kebenaran akses pemanfaatan di wilayahnya.

Pada fasal 12 (1) RUU-PTEBT menyatakan bahawa setelah mendapat kebenaran untuk mengakses penggunaan ekspresi budaya tradisional sebagaimana dimaksud dalam fasal 6 (10), pemohon wajib melakukan perjanjian penggunaan ekspresi budaya tradisional dengan pemilik ekspresi budaya tradisional atau oleh agensi-agensi pengurusan kolektif dalam tempoh setahun sejak kebenaran akses untuk menggunakan ekspresi budaya tradisional tersebut diberikan.

Apabila dikaitkan dengan peruntukan yang ada dalam Rang Undang-Undang Pengetahuan Tradisional dan Ekspresi Budaya Tradisional, maka menjadi keperluan untuk memenuh syarat dalam beberapa peruntukan, antara lain fasal 15 dan fasal 16 dalam rang undang-undang. Dalam fasal 15 Rang Undang-Undang Pengetahuan Tradisional dan Ekspresi Budaya Tradisional terkait dengan pihak yang melakukan pemanfaatan, disebutkan bahawa:

1. Pihak yang melakukan pemanfaatan wajib melakukan perkongsian faedah atas pemanfaatan ekspresi budaya tradisional kepada pengguna ekspresi budaya tradisional sesuai dengan kesepakatan yang dituangkan di dalam perjanjian pemanfaatan; 
2. Akses perkongsian faedah atas pemanfaatan ekspresi budaya tradisional sebagaimana dimaksud pada (1) ditentukan berdasarkan kesepakatan dengan memperhatikan kepada kepatutan dan kewajaran.

Seterusnya Fasal 16 RUU-PTEBT pula menyebutkan bahawa:

1. Penjaga ekspresi budaya tradisional berhak menerima manfaat dari penggunaan ekspresi budaya tradisional dan dari pemegang kebenaran akses untuk menyatakan budaya tradisional sesuai dengan kesepakatan yang ditetapkan dalam perjanjian eksploitasi ekspresi budaya tradisional.

2. Penjaga yang disebut dalam perenggan (1) hendaklah menggunakan aspek penyertaan yang ada dalam ekspresi budaya tradisional sebagai pemeliharaan dan pembangunan ekspresi budaya tradisional.

Fasal 63 (1) (I) RUU-PTEBT memberi mandat kepada pemerintah untuk menetapkan dan melaksanakan dasar mengenai ekspresi budaya tradisional. Sebagai syarat objektif lainnya adanya objek tertentu, dan hal ini dapat dipastikan bahawa wujud ekspresi budaya tradisional yang memiliki nilai ekonomi, maka ianya boleh dimasukkan ke dalam Rang UndangUndang Pengetahuan Tradisional dan Ekspresi Budaya Tradisional ini.

Selain daripada dalam merangka rang undang-undang ini, dalam mengukuhkan rang undangundang ini, kerajaan Indonesia telah menyatakan beberapa strategi dalam memberi perlindungan ekspresi budaya tradisional seperti inventori dan pangkalan data perlindungan warisan budaya tradisional, pemuliharan warisan budaya tradisional, perkongsian faedah dalam perlindungan warisan budaya tradisional, dan perlindungan sui generis ekspresi kebudayaan tradisional.

Oleh itu, RUU-PTEBT merupakan satu usaha kerajaan Indonesia dalam memberikan perlindungan pada ekspresi budaya tardisional ini. Rang undang-undang ini akan menunjukkan bahawa betapa seriusnya kerajaan Indonesia dalam melindungi ekspresi budaya tardisional yang dimiliki oleh masyarakat tradisional Indonesia dan ini secara tidak langsung kerajaan Indonesia dapat melindungi hak rakyatnya.

\section{KESIMPULAN}

Ekspresi budaya tradisional ini muncul daripada hasil kreativiti pemikiran masyarakat tradisional dalam kitaran kehidupan harian mereka. Oleh itu, masyarakat tradisional sangat menghargai ekspresi budaya tradisional ini kerana mempunyai makna yang penting dan memberi pengaruh dalam kehidupan mereka, di samping ekspresi budaya tradisional ini mengandungi nilai-nilai agama, roh dan kepercayaan nenek moyang mereka.

Namun begitu yang menjadi masalah adalah apabila ada pihak terutama negara maju cuba untuk menggunakan ekspresi budaya tradisional ini tanpa kebenaran masyarakat tradisional dan menjadikan ekspresi budaya tradisional ini sebagai sumber pendapatan mereka serta mewartakannya sebagai hak cipta terpelihara mereka. Hal ini telah menyebabkan masyarakat tradisional kehilangan budaya yang dipertahankan dan secara tidak langsung mengugat 
sumber pendapatan masyarakat tradisional itu sendiri. Oleh itu, RUUPTEBT ini perlu dibentang dan digubal dengan segara di Parlimen supaya menjadi satu akta yang boleh memperkasakan dan melindungi nilai ekspresi budaya tradisional ini. Pewartaan RUU-PTEBT ini akan memartabatkan nilai ekpresi budaya tradisional masyarakat tradisional Indonesia.

\section{NOTA}

DokumenWIPO/GRTKF/IC/19/4:http://w ww.wipo.int/edocs/mdocs/tk/en/wipo_grt kf_ic_19/wipo__grtkf_ic_19_4.pdf : "Protection (shall) should extend to any traditional cultural expression which is the (unique]/indicative) characteristic product of a people or community, including an indigenous people orlocal community and cultural communities or nations and (belongs to) isused and developed by that people or community (as part of their cultural or social identity orheritage). Protected traditional cultural expressions shall be: (a) the products of (creative intellectual activity), including communal creativity; (b) indicative of (authenticity/being genuine) of the cultural and social identity and cultural heritage of indigenous peoples and communities and traditional and other culturalcommunities; and (c) maintained, used or developed by nations, states, indigenous peoples and communities and traditional and other cultural communities, or by individuals havingthe right or responsibility to do so in accordance with the customary land tenuresystem or law / customary normative systems or traditional/ancestral practices ofthose indigenous peoples and communities and traditional and other culturalcommunities, or has an affiliation with an indigenous/traditional community.

\section{RUJUKAN}

Abdul Atsar. 2017. Perlindungan hukum terhadap pengetahuan dan ekspresi budaya tradisional untuk meningkatkan kesejahteraan masyarakat ditinjau dari UndangUndang NO. 5 Tahun 2017 tentang pemajuan kebudayaan dan Undang-Undang No. 28 Tahun 2014 Tentang Hak Cipta. Jurnal Law13 (2):285

Afriliyana Purba. 2012. Pemberdayaan Perlindungan Hukum

Pengetahuan Tradisional dan Ekspresi Budaya Tradisional Sebagai Sarana Pertumbuhan Ekonomi Indonesia. Bandung: Alumni.

Agus Sardjono. 2009. Membumikan HKI di Indonesia. Bandung: Nuansa Aulia.

Agus Sarjono. 2011. Culture and intellectual property development in Indonesia. Indonesia Law Review 3: 241.

Bainbridge, D. 2010. Intellecual Property, My Law Chamber. English.

Blankey, M. 2011. Protecting of traditional knoeledge and traditional culture expression. Quen Mary Intellectual Property Journal: 82-83.

Copinger. et al. 1998. Copinger and Skone James on Copyright. LAndon: Sweet \& Maxwell.

Detik News. 2008. Tuding Jiplak Motif Perak, Perajin Bali Dituntut 2 tahun Penjara. Detik News. https://news.detik.com/berita/100 5035/dituding-jiplak-motifperak-perajin-bali-dituntut-2tahun-penjara, di akses pada 10 September 2012.

Dewan Pelestarian Nilai Budaya. 2015. Dirjen HKI - Dept. Hukum dan HAM RI. 2009. Peranan Sistem Hak Kekayaan Intelektual Dalam Melindungi Pengetahuan Tradisional dan Ekspresi Budaya Tradisional. Yogyakarta: Lokakarya Nasional PT-EBT.

Drahos, P. 2007. Thinking strategically about intellectual property rights, 
World Patent Information 29: 255-261.

Edi Sedyawati. 2003. Keindonesiaan Didalam Budaya Buku 2 Dialog Budaya: Nasional dan Etnik Peranan Industri Budaya dan Media Massa Warisan Budaya dan Pelestarian Dinamis. Jakarta:Wedatama Widya Sastra.

Eva Damayanti. 2002. Hukum Merk Tanda Produk Industri Budaya. PT: Alumni.

Eva Damayanti. 2012. Hukum Merk Tanda Produk Industri Budaya. Jakarta: Gramedia Pustaka.

Geertz, C. 1973. The Interpretation Of Cultures. Basic Books, Inc., Publishers.

Harding, S. 2003. Defining traditional knowledge-lessons from cultural property. Cardozo J. Int'l \& Comp. L. [v] Table of Contents 11(2): 511.

I Wayan Ardika. 2007. Pusaka Budaya dan Pariwisata. Denpasar: Pustaka Larasan.

Jamaludi Abu Bakar. 2002. Memahami Harta Intelek. Selangor: Dunia Ilmu Enterprise.

Janke, T. 1998. Our Culture Our Future: Report on Australian Indigenous Cultural and Intellectual Property Rights. Michael Frankel \& Co.

Lembaga Pengkajian Hukum Internasional Fakultas Hukum Universitas Indonesia bekerjasama dengan Ditjen HKI Departemen Hukum dan HAM. 2005. Kepentingan Negara Berkembang Terhadap Hak Indikasi Geografis,Sumber Daya Genetika dan Pengetahuan Tradisional. Indonesia.

Lindsey, T. et al. 2008. Hak Kekayaan Intelektual: Suatu Pengantar. Jakarta: Gramedia Pustaka.

M Zulfa Aulia. 2006. Perlindungan Hak Kekayaan Intelektual atas
Pengetahuan

Tradisional. Jakarta: FH UI

Miriam Budiarjo. 2003. Dasar-Dasar Ilmu Politik. Jakarta: PT. Gramedia Pustaka Utama.

Model Provision For National Laws On The Protection Of Expression Of Folklore Againts Illicit Exploitation and OtherPrejudicial Actions 1985.

OK Saidin. 2010. Aspek Hak Kekayaan Intelektual (Intellectual Property

Right). Pt. Raja Grafindo Persada.

Posey, D. A. 2011. Introduction: Cultural and Nature - The Inextricable Link", dalam UNEP, Cultural and Spiritual Values of Biodiversity. Intermediate Technology Publications.

Restu Gunawan. 2014. Sejarah Indonesia. Jakarta: Kementerian Pendidikan dan Kebudayaan.

Sutejo K. Widodo. 2004. Memaknai Sumpah Pemuda di Era Reformasi. Jakarta: Yayasan Gedung Bersejarah.

Palmer, T. G. 2007. Are patents and copyrights morally justified? The philosophy of property rights and ideal objects. Harvard Journal of Law and Public Policy, 13(3): 822.

Swiderska1, K., Daño, E. \& Dubois, O. 2001. Developing The Phulippines Executive Oreder No. 247 On Access To Genetic Resources. Participation in Access and Benefit-Sharing Policy Case Study no 4.

Tri Harjun Ismaji. 2009. Sekretaris Daerah Istimewa Yogjakarta, dalam Matriks Data Pengetahuan Tradisional dan Ekspresi Budaya Tradisional (PTEBT). Indonesia: Badan Pembinaan Hukum Nasional 
Departemen Hukum Dan HAM

R.I.

Undang-Undang Hak Cipta No. 28

Tahun 2014

Yulia \& Zainul Ashikin Zainol. 2013.

Melindungi keanekaragaman

hayati dalam kerangka protokol

Nagoya. Mimbar Hukum 25(2):

272.

Ayu Citra Santyaningtyas

Fakulti Undang-Undang,

Universiti Kebangsaan Malaysia

436000 UKM Bangi, Selangor

E-mel: ayuaditya17312@gmail.com

Rasyikah Md Khalid

Fakulti Undang-undang,

Universiti Kebangsaan Malaysia

436000 UKM Bangi, Selangor

E-mel:rasyikah@ukm.edu.my

Nur Fadzlun Johan

Universiti Kebangsaan Malaysia

436000 UKM Bangi, Selangor

E-mel:fadzlunjohan@yahoo.com 